\title{
Teaching and Resistance at a Neo-Liberalised University: A Teacher's Critical Reflection and Calling for Praxis Actors in the Post-Modern Professional Age
}

\author{
Yulong Li1, Xiaojing Liu ${ }^{2^{*}}$ \\ ${ }^{1}$ Faculty of Humanities and Social Sciences, City University of Macau, Macau, China \\ ${ }^{2}$ College of Teacher Education, Lingnan Normal University, Zhanjiang, China \\ Email: *xjliuwork@foxmail.com
}

How to cite this paper: Li, Y. L., \& Li, X. J. (2020). Teaching and Resistance at a Neo-Liberalised University: A Teacher's Critical Reflection and Calling for Praxis Actors in the Post-Modern Professional Age. Open Journal of Social Sciences, 8, 1-12.

https://doi.org/10.4236/jss.2020.812001

Received: November 17, 2020

Accepted: November 28, 2020

Published: December 1, 2020

Copyright $\odot 2020$ by author(s) and Scientific Research Publishing Inc. This work is licensed under the Creative Commons Attribution International License (CC BY 4.0).

http://creativecommons.org/licenses/by/4.0/

\begin{abstract}
Under the neo-liberalism attack, many universities across the world have resorted to a centralised curriculum, streamlined assessment, commercialised management and a de-professionalisation and exploitation of teachers, as a means to maximise profits as a result of the capitalist hegemony. Teachers' professionalism is facing a severe challenge. This critical review starts by discussing a university teacher's experience of overwork at a neo-liberalized university in Hong Kong, and then a theoretical analysis and critique of the spread of neoliberalism is delivered. In order to provide a possible solution to such phenomenon, this essay stresses the importance of a resistance culture, particularly teachers becoming actors of praxis to use their moral commitments to decide what is right for students, society, and humanity, so as to mediate or change the status quo of the endangered professionalism in such post-modern age of neo-liberalisation.
\end{abstract}

\section{Keywords}

Neo-Liberalism, Post-Modern Professionalism, Teacher Resistance, Praxis

\section{Introduction: The Endangered Professionalism and the Traditional Motto of Higher Education}

Teachers pass through four different professional ages: the pre-professional, the autonomous professional, the collegial professional, and the post-modern professional age (Hargreaves, 2000). At each professional age, teachers are required to undertake different kinds of professional learning. In the pre-professional age, 
teachers do not need much professional learning, except for referring to their own previous teachers as resources on how to keep a large number of students studying while also disciplining their behaviour; in the autonomous professional age, teachers refer to their preferred theories and university training as their source of knowledge; in the collegial professional age, teachers learn from each other to cope with increasingly complex social issues affecting schools (Hargreaves, 2000). Finally, in the post-modern professional stage, it is generally where I am in, neo-liberalised strategies at the national and international levels are intruding into education, where profit is the priority, leading to centralised curricula, streamlined assessment, and standardised commercialised management in schools (Hargreaves, 2000). Hargreaves (2000) argued that in the current age, teachers are being de-professionalised, and encouraged teachers to fight against de-professionalism; however, little direction was provided regarding what resources teachers should rely on and in what specific way(s) teachers should develop their professional learning in the post-modern age.

From a critical theory perspective, neo-liberalism questions the long-held moral foundation of higher education as a democratic public good, and seeks to apply marketization theory (Giroux, 2002), polluting academic identity and value with market sense and economic gains (Giroux, 2011). Through a Gramscian (1971) lens, neo-liberalism becomes hegemonic, and it propagates a common sense that corporatisation is the direction higher education should move in (Giroux, 2002). As a result, many universities and education practitioners consent to the hegemony (e.g., Quinn \& Bates, 2017; Choi, 2010). However, by contrast, education and schools are also at the heart of counter-hegemony, where any social transformation and deviation away from the hegemony must start with educating students and raising their praxis to develop good sense (Mayo, 2008; Gross, 2011). As a prerequisite of the praxis, teachers should become organic intellectuals (Gramsci, 1971) using critical consciousness to withdraw their consent to the injustice and oppression of neo-liberal hegemony in education.

Kemmis and Smith (2008) emphasised the importance of teachers becoming actors of praxis by arguing that, regardless of intellectual and cultural traditions, praxis requires teachers to use moral commitments to decide what is right for students, society, and humanity. Therefore, referring to Hargreaves (2000), in the age of post-modern professional age, praxis should be the professional learning teachers undertake. With such praxis, teachers can mediate or change the status quo.

\section{An Auto-Ethnographic Experience of the Author as a University Teacher in a Neo-Liberalised University}

This section will begin with a detailed description of my situation, and the personal rationale for planning this study, which guides my interpretation of the dominant neo-liberalism in higher education. I once worked in the graduate school at a publicly funded university in Hong Kong. By the time this study was conducted, I was supervising two master students in their research projects. In 
addition, I was coordinating and teaching on three taught masters' modules, including the subjects of research methods and teacher development. The academic year saw one-third increase of student enrolment on masters' programmes. I was tasked with teaching, marking assignments, and providing spontaneous consultation to almost 200 students in my own lessons alone. The increase in student enrolment has resulted in significant growth in the previously smaller size class, to approximately 60 students, significantly hindering many classroom activities and decreasing learning efficacy. The students' entrance requirement into the university quality was also lowered, forcing teachers to arrange further consultation for students to address problems they had failed to resolve in class. In addition to teaching masters students, I was also required to advise research doctoral students on their academic writing. Due to my mainland Chinese heritage background, I was assigned a further role by the dean of the graduate school, my line manager: to make connections with partner universities in mainland China and to lead study trips there from Hong Kong. The year before, I led and organised five visits to Mainland China, and also provided receptions for five visitor groups from partner universities from China. Within the graduate school, the dean requested that I design an inventory and pilot for his project, a knowledge transfer project, and write a sabbatical report. A few months previously, the colleague responsible for organising the annual international summer school resigned; the role was automatically passed to myself, due to my previous involvement in this area.

My job description might suggest I was an essential figure in the graduate school. In reality, I was a lecturer (previously known as teaching fellow) on a temporary contract. The reason that I, a lecturer, was present in an administrative department of the graduate school was because I was able to offer English for Academic Purposes (EAP) service to doctoral students; however, I later was assigned additional duties as the dean sought to justify my salary. My original contract was only for one year; at the end of each contract, the dean of the graduate school made a decision on whether I was still needed. By the time of doing this study, I was on my second contract. I was only entitled to 12-day annual leave. During the first contract, about then I was newly married, and a year later my grandmother passed away; I was not entitled to any bereavement or marital leave, all of my leave was deducted from the standard 12 days.

Shouldering the heavy teaching workload, I was even criticised by the dean of the graduate school for spending too much time tutoring the students. The dean had returned from sabbatical and seen students queuing to see me discuss their assignment structures, and had assumed that this limited the time I had to work on his projects and write his sabbatical report. However, I was burning myself out, taking work home to prepare new lessons and gave students feedback in the evenings and at the weekend. For some times, I could not help asking as a teacher, should teaching always be my primary job? Years of working at the university had broken my professionalism as a teacher; I was not held in any esteem as a teacher. Sitting with all the administrative staff in a large office, outside the 
dean's office, I felt constantly under surveillance by the line managers, and was often summoned at their fingertips. This has left me with little time to prepare my own publications; however, being a university lecturer in Hong Kong, a high quantity and quality of publications seems to be a necessity for future promotion and career prospects.

This situation led to a personal dilemma for me at that time: should I continue to spend more time teaching and on student consultations, or should I sacrifice the energy I spend teaching on completing the various tasks that are spontaneously assigned to me? This gave rise to a further, more profound dilemma: I am still young, how this will ensure my development as an early-career academic if I am being coerced into giving up most of the time I have available for teaching and research? Am I a teacher, or an office clerk?

Faced with this dilemma, I made the decision to resist the hegemony by acting irresponsibly to the spontaneous tasks I was given by only using a small fraction of time on the office errands, and I decided to spend as much time as I could to ensure the quality of my teaching, while using more time to work on my publications and reading. My behaviour is a kind of a Foucauldian (1990) resistance, where, "by acting 'irresponsibly' these teachers take 'responsibility' for the care of their selves"; teachers use the care of selves as a counter-conduct to mediate the power on them. My field of practice has given rise to a personal concern about how other early-career academics experience working in neo-liberalised universities in Hong Kong and beyond. From my experience I try to relate to a larger background of the neoliberalism in higher education.

\section{The Neo-Liberalised Higher Education, Corporate Value, Accountability Managerialism, and Hegemony}

Neo-liberalism, also known as Thatcherism, is a national policy that was initiated at the time when the former UK Prime Minister Margaret Thatcher and the former US President Ronald Reagan came to power (Cahill \& Konings, 2017). Based on neo-classical economic theory, it aimed to promote free market competition in public spheres and government departments, for example transportation and education, in order to improve on the so-called stifled and ineffective welfare state (Cahill \& Konings, 2017; Kivisto, 2018). Neo-liberalism is based on the assumption that market compensation and the competition is meritocratic. Therefore, the market could be a screening filter to reward the efficacious and punish the poorly performing departments (Kivisto, 2018). Against this backdrop, schools and universities were incorporated and had to compete with each other to win market position (Giroux, 2002; Quinn \& Bates, 2017).

Meanwhile, the so-called "free" market becomes a camouflage of the increasing governance; the neo-liberal government also tightens its control over public bodies via overseeing and promoting performance (Raaper, 2016). A top-down accountability managerial strategy, such as use of performance-based indicators and performance-related pay or budgets, has been introduced to universities in many parts of the world (Wilkesmann \& Lauer, 2018). In line with a decrease in 
higher education budgets from governments, universities have had to lower their costs and raise revenue (Dugas, Stich, Harris, \& Summers, 2018).

In the late 1990s, the University Grants Committee (UGC) in Hong Kong opened up a branch entitled the Quality Assurance Committee (QAC) as a third-party organisation monitoring the quality of local higher education institutions (Mok, 2001). This marked the beginning of the neo-liberalisation of universities in Hong Kong. Such commercialisation did not face much resistance (Choi, 2010); arguably, this is because Hong Kong is built on commerce, and so people took the capitalisation of higher education for granted, giving consent to the dominant neo-liberal sentiment. As an insider of neo-liberalised higher education in Hong Kong, I ethnographically observed five phenomena in my university: competing for university ranking; pushing for staff publications; pushing staff into completing research for and securing funding from external parties; running new courses driven by market need; sacrificing teaching quality and teacher welfare.

Generally speaking, university rankings are the result of economic evaluation undertaken by third-party commercial units. The rankings were created for and based on the standards of Anglo-Saxon origin institutions, but the rankings have become important for institutions elsewhere in order to compete internationally (Ordorika \& Lloyd, 2015). Over the years, universities in Hong Kong have begun to compete fiercely in the rankings. The university I work at also celebrates achieving higher rankings, as the reputation it builds will not only increase student enrolment and cash flow, but also, and most importantly, strengthen its market position (Quinn \& Bates, 2017).

As international publication is a significant indicator used in the rankings, my university has gone to great efforts to recruit scholars with a strong record of publications to join the academic staff. In order to motivate the research output of faculty members, UGC initiated a Research Assessment Exercise (RAE) department, whose function it is to calculate and evaluate the international publications of academic staff. In my university, academic staffs are evaluated on the basis of their annual publications in high performance journalism as selected by the Research Development Office (RDO) based on Scimagojr. Over the course of three years, every member of the academic staff must produce at least one A or $A^{*}$ level SSCI publication as the first or corresponding author; and, annually, they must produce at least two journal articles above B level, confirmed by the RDO. These publication demands only account for half of the academic staff's research workload; the other half consists of securing research funding from external funders.

Academic staffs are pressured to secure funding from external parties. At my university, there is an unwritten regulation that only General Research Fund or Early Career Scheme Fund holders are eligible to supervise PhD students. Securing funding ensured teachers' position in the departments. Recently, a colleague was recruited as a senior research assistant onto a research project on improving students' study of Chinese literacy through use of cartoons, funded by 
the Happy Clown Foundation in Hong Kong (a pseudonym for a foundation built on horse racing gambling and lottery money). According to this colleague, the scale of this project was so large that it involved more than ten academic staff across three departments; the university seized all possible opportunities to broadcast its involvement in the project online, and even held a press conference to highlight the winning of the bid from the Happy Clown. Working under the founder's name, the academics involved became advertisers and representatives of the gambling and lottery industry. In this manner, commercialisation entered the university. The university also has departments sponsored and named after commercial tycoons, e.g., The Big Tycoon Centre for Education (pseudonym). The Big Tycoon is a real estate tycoon notorious for his involvement in money laundering in Macao 2014. In return for funding, the university conferred a doctoral degree honoris causa on the Big Tycoon's son in 2015. Discussing this phenomenon of naming and branding, Giroux (2002) warned that such cooperation opened the gateway for the commercial tycoons to interfere with academics in higher education; influencing the kind of research they conduct. External bodies like this encourage universities to produce applied knowledge targeted at understanding customers, eschewing the traditional role of the university to generate powerful knowledge for the sake of human development (Hordern, 2018).

Driven by the market needs, the university established an EAP master's programme in 2016, due to the increasing popularity of EAP (Thompson \& Diani, 2015). In 2018, with the development of STEM education, the university launched a STEM master's programme. When the master's in EAP was launched, it was one of the first universities in the Greater China area providing such a course; however, when the first cohort of 25 students were enrolled, the university did not have a complete curriculum ready. Of the four core modules of the EAP course, two of them were offered by adjunct lecturers, one was offered by two lecturers invited from the Language Centre at Coventry University in the UK, who delivered the course intensively over a month. The only module offered by the university's own academic staff was developed and temporarily passed at the graduate board meeting in the second semester. The decision to invite adjunct and part-time teachers to teach the EAP students was not made because the university did not have the relevant academic staff, but because, according to the module coordinator, they were too busy with research and did not have time to teach newly launched programmes. Giroux (2002) criticised a similar situation, describing the practice of US universities hiring adjunct and part-time staff to teach students as "cheating".

With the increased number of students, the president of the university decided to recruit more teaching fellows (now renamed "lecturers") to share the teaching load of the academic staff. These lecturers are burdened with large teaching loads and administrative duties, with no research output. To the best of my knowledge, this community is made up mostly of doctoral graduates from local universities who are less competitive compared with their counterparts 
who graduated from UK or US institutions, who sit at the top of the academic geo-scientific hierarchy (Bauder, Lujan, \& Hannan, 2018), and those with less teaching experience. I myself am a member of this community. According to market sense, and similar to the role of graduate teaching assistants described by Raaper (2017: p. 421), we have become "mediators between demanding students and overworked academics".

Despite the unfairness of this system in higher education, there seems to be no willingness to pause and to reflect; the neo-liberalisation has become hegemony. Livingstone (1976: p. 235) defines hegemony as the phenomenon where "all aspects of social reality are dominated by or supportive of a single class". The neo-liberal hegemony attempts to control the academic staff by instilling corporate values and evaluating performances according to the values of instrumental management, at the expense of academics' job satisfaction, academic identity, teaching quality, and social justice (Jones \& Patton, 2018; Dugas, Stich, Harris, \& Summers, 2018).

\section{The Disappearance of Higher Education as a Public Good, Conscience, and as an Arena for Political Action}

The fiercest debate over neo-liberalised higher education surrounds the question of what the true purpose of a university is: as an instrumental service provider, or the democratic public conscience (Giroux, 2002). Proponents of the former appear currently to be winning the debate (Choi, 2010). The traditional values of the university as a public good conferred academics a high degree of self-regulation, academic freedom, institutional autonomy, and collegial involvement in institutional decision-making (Dugas, Stich, Harris, \& Summers, 2018). However, the neo-liberalised universities, by adopting top-down accountability management, have increased the authority of academic managers (Giroux, 2002), involved external stakeholders in decision-making (de la Torre, Rossi, \& Sagarra, 2018), and endangered academics' time, space, voice, and identity (Dugas, Stich, Harris, \& Summers, 2018).

In the debate of what the true purpose of education is, the less dominant view is of education as a public conscience and as a space for political acts (Freire, 1996). For a long time, critical educators have pointed out that the ruling class used streamlined curricula and content to institutionalise teachers and students and stifle the critical thinking of the majority (Freire, 1996; Giroux, 2011), while true educators, as organic intellectuals, should drive democratic social transformation by questioning social injustices, oppression, and the common sense (Giroux, 2011; Gramsci, 1971; Freire, 1996). Chomsky (2000: p. 35) explained, "The social and intellectual role of the university should be subversive in a healthy society". However, not all intellectuals are political; in the all-encompassing neo-liberal environment, many of them choose to pursue promotion and tenure (Shear, 2008), and many others uncritically treat neo-liberalism as the "right way" (Quinn \& Bates, 2017). In recent years, Hong Kong universities have 
tended to be more politically neutral (Lo, 2015). The former president of the University of Hong Kong, Peter Mathieson (2015, Dec, 17, retrieved from http://www4.hku.hk/cpao/bulkmail/2015/President/Court/Speech/Court2015.pd f), publicly expressed: "I and the senior management team have stuck to our principles, remained politically neutral and continued to be driven by our commitment to maintain and enhance the high standards of excellence in teaching, research and knowledge exchange which characterise and define Hong Kong U and must continue to do so." Being politically neutral has made instrumentality unavoidable in neo-liberal Hong Kong universities, announcing higher education as public conscience a story in the past and a residual knowledge.

\section{A Possibility for Resistance, Consent, and Counter-Hegemony}

The reports of increasing resistance indicate the incompleteness of neo-liberal hegemony (Massey, 2013). This counter-hegemonic resistance has occurred at all levels of the global economy (Gibson-Graham, 2006). For example, librarians from the UK and Ireland united to form a Radical Library Collective, utilising online and off-line gatherings to galvanise and communicate and to resist marketisation (Quinn \& Bates, 2017). At the Chinese University of Hong Kong, some teachers and students went on strike to express their objection towards the university replacing Chinese with English as the primary medium of instruction (Choi, 2010). In contrast to the open and organised resistance, Raaper (2016, 2018) and Ball and Olmedo (2013) have observed some more subtle, inward, and everyday forms of resistance to neo-liberalised higher education amongst teachers and graduate teaching assistants. Academics repeatedly expressing job dissatisfaction, teaching or research disengagement, and identity struggles have also been recorded by Dugas et al. (2018), Wilkesmann and Lauer (2018), and Jones \& Patton (2018).

However, Raaper (2018) points out that many academics, despite being exploited and feeling resistant, will endure the unfair treatment and view it as an opportunity to build up work experience and devotion to academia, hoping for a better position in the future. From a Gramscian perspective, the passive acceptance of the oppression and devotion to the neo-liberalised academia was giving consent to the hegemony (Gross, 2011).

The underlying and public resistance to the neo-liberalised university has also been evident in my own personal experience. Recently, the contract of a lecturer in the department of linguistics was discontinued after teaching at the university for three years. This occurred just prior to the RAE implementing examination of staff's research outputs every four years. The colleague in question sent a group email to every member of staff in the university, suspecting that the university blamed her lack of publications for the department's RAE result. In the email, she explained that in the past three years she had taught 17 modules to both undergraduates and postgraduates, stating teaching occupied all of her 
time, leaving her with little energy to undertake any research. She expressed that she felt she had been treated unfairly, like the university had betrayed her contributions. With no agreement on continuation of her contract reached with the university, she reported her experiences to a local newspaper. I had hoped that this might be a catalyst for other university teachers to reflect and to unite; however, there was no response from other teachers.

Gramsci positioned education at the core of attempts to tackle hegemony (Mayo, 2008). As education is where common sense is instilled, educators should play pivotal roles in using praxis to lead students to wage war on the hegemony (Gross, 2011). Freire emphasised that in praxis educators should take action against the oppression as, without real action, even critical reflection has a tendency to acquiesce to inequality - in other words, to consent to hegemony (Howlett, 2013). Using Gramsci's (1971) lenses, some of the resistance and their initiators, such as those mentioned in Raaper (2018), even though they provide critical reflection on the hegemony, were in fact consenting to it.

\section{Conclusion: Calling for the Praxis Actors in the Neoliberal Time}

There are many different features of research; one that is widely recognised is its relationship with knowledge processing and production. According to Gratton and Jones (2010: p. 4) research is "a systematic process of discovery and advancement of human knowledge". Different research traditions have required practitioners to use different epistemological lenses to look at the world and then to enrich knowledge (Hartas, 2010). However, research occurs within different traditions, e.g., positivist, interpretivist, and Marxist. Due to the academic hierarchy formulated after World War Two, with Anglo-American intellectuals sitting at the top, positivist research has dominated and been pervasively promoted (Parmar, 2002). However, intellectuals from the Marxist Frankfurt School criticised positivism's blind worship of rationality and superficial accounts of phenomena (Inglis \& Thorpe, 2012). However, regardless of the rationality or superficiality of accounts of phenomena, positive knowledge is usually transformed into content knowledge in school curricula and textbooks by the ruling class (Horkheimer, 1972). Such knowledge falls under the category of the techne form of knowledge of Aristotle, who conceptualised episteme, techne, and phronesis as three knowledge strata (Kemmis \& Smith, 2008). Techne knowledge is an only craft; for teachers, it is related to the skills of teaching and learning. However, education is a moral activity, requiring teachers to act for the benefit of the students, society, and humanity (Kemmis \& Smith, 2008). Research from a positivist tradition; therefore, can only lead to improved skills and practice for teachers on a techne level.

In order to fulfill their moral commitment as educators, teachers should develop phronesis, as the mentality of making prudent decisions in an uncertain and perplexing context; most importantly, they should develop practice into 
praxis, the action of phronesis, acting for the well-being of the students and society (Kemmis \& Smith, 2008). Regarding the development of phronesis, Kemmis and Smith (2008) ask teachers to critically reflect on the circumstances of the students and the schools, and on cultural, historical, discursive injustice. To further facilitate the development of phronesis, action research with an emancipatory nature (Carr \& Kemmis, 1986) may better stimulate teachers' critical reflection and praxis. The future study proposed by me in this essay, if carried out, may encourage the research participants to think, question, and to critique the powers around them; this will become their reflection on the power and reflexivity of selves, which will plant the seeds for nurturing their praxis.

\section{Conflicts of Interest}

The authors declare no conflicts of interest regarding the publication of this paper.

\section{References}

Ball, S. J., \& Olmedo, A. (2013). Care of the Self, Resistance and Subjectivity under Neoliberal Governmentalities. Critical Studies in Education, 54, 85-96. https://doi.org/10.1080/17508487.2013.740678

Bauder, H., Lujan, O., \& Hannan, C. A. (2018). Internationally Mobile Academics: Hierarchies, Hegemony, and the Geo-Scientific Imagination. Geoforum, 89, 52-59. https://doi.org/10.1016/j.geoforum.2018.01.004

Cahill, D., \& Konings, M. (2017). Neoliberalism. Cambridge: Polity Press.

Carr, W., \& Kemmis, S. (1986). Becoming Critical. Education, Knowledge and Action Research. London: Falmer.

Choi, P. K. (2010). "Weeping for Chinese University”: A Case Study of English Hegemony and Academic Capitalism in Higher Education in Hong Kong. Journal of Education Policy, 25, 233-252. https://doi.org/10.1080/02680930903443886

Chomsky, N. (2000). Paths Taken, Tasks Ahead. In Profession 2000 (pp. 32-39). New York: Modern Language Association.

de la Torre, E. M., Rossi, F., \& Sagarra, M. (2018). Who Benefits from HEIs Engagement? An Analysis of Priority Stakeholders and Activity Profiles of HEIs in the United Kingdom. Studies in Higher Education, 44, 2163-2182. https://doi.org/10.1080/03075079.2018.1479847

Dugas, D., Stich, A. E., Harris, L. N., \& Summers, K. H. (2018). "I’m Being Pulled in Too Many Different Directions": Academic Identity Tensions at Regional Public Universities in Challenging Economic Times. Studies in Higher Education, 45, 312-326. https://doi.org/10.1080/03075079.2018.1522625

Freire, P. (1996). Pedagogy of the Oppressed. London: Penguin. https://doi.org/10.1007/978-1-349-25349-4_25

Gibson-Graham, J. K. (2006). A Postcapitalist Politics. Minneapolis, MN: University of Minnesota Press.

Giroux, H. (2011). Rejecting Academic Labor as a Subaltern Class: Learning from Paulo Freire and the Politics of Critical Pedagogy. Fast Capitalism, 8, 35-40. http://www.uta.edu/huma/agger/fastcapitalism/8_2/Giroux8_2.html https://doi.org/10.32855/fcapital.201102.004 
Giroux, H. A. (2002). Neoliberalism, Corporate Culture, and the Promise of Higher Education: The University as a Democratic Public Sphere. Harvard Educational Review, 72, 425-463. https://doi.org/10.17763/haer.72.4.0515nr62324n71p1

Gramsci, A. (1971). Selections from the Prison Notebooks of Antonio Gramsci. Q. Hoare, \& G. N. Smith (Eds.) \& (Transl.). New York: International Publishers.

Gratton, C., \& Jones, I. (2010). Research Methods for Sports Studies. London: Routledge.

Gross, J. P. K. (2011). Education and Hegemony: The Influence of Antonio Gramsci. In B. A. U. Levinson, J. P. K. Gross, C. Hanks, J. H. Dadds, K. D. Kumasi, J. Link, \& D. Metro-Roland (Eds.), Beyond Critique Exploring Critical Social Theories and Education (pp. 51-79). London: Paradigm Publisher.

Hargreaves, A. (2000). Four Ages of Professionalism and Professional Learning. Teachers and Teaching: Theory and Practice, 6, 151-182. https://doi.org/10.1080/713698714

Hartas, D. (2010). Educational Research and Inquiry: Key Issues and Debates. In D. Hartas (Ed.), Educational Research and Inquiry: Qualitative and Quantitative Approaches (pp. 13-29). London: Continuum.

Hordern, J. (2018). Is Powerful Educational Knowledge Possible? Cambridge Journal of Education, 48, 787-802. https://doi.org/10.1080/0305764X.2018.1427218

Horkheimer, M. (1972). “The Social Function of Philosophy” in Critical Theory: Selected Essays. New York: Herder and Herder.

Howlett, J. (2013). Progressive Education: A Critical Introduction. London/New York: Bloomsbury Academic.

Inglis, D., \& Thorpe, C. (2012). An Invitation to Social Theory. Cambridge: Polity.

Jones, D. R., \& Patton, D. (2018). An Academic Challenge to the Entrepreneurial University: The Spatial Power of the "Slow Swimming Club". Studies in Higher Education, 45, 375-389.

Kemmis, S., \& Smith, T. J. (2008). Personal Praxis: Learning through Experience. In S. Kemmis, \& T. J. Smith (Eds.), Enabling Praxis Challenges for Education (pp. 15-35). Rotterdam: Sense Publisher. https://doi.org/10.1163/9789087903275_003

Kivisto, H. (2018). Capital as Power and the Corporatization of Education. Critical Studies in Education, 59, 313-329. https://doi.org/10.1080/17508487.2016.1186707

Livingstone, D. W. (1976). On Hegemony in Corporate Capitalist States: Material Structures, Ideological Forms, Class Consciousness, and Hegemonic Acts. Sociological Inquiry, 46, 235-250. https://doi.org/10.1111/j.1475-682X.1976.tb00768.x

Lo, S. (2015). Perspectives on the Occupy Central Movement. In J. Gagnon, \& M. Chou (Eds.), Hong Kong’s Indigenous Democracy (pp. 104-137). London: Palgrave Macmillan. https://doi.org/10.1057/9781137397140_5

Massey, D. (2013). Vocabularies of the Economy. Soundings: A Journal of Politics and Culture, 54, 9-12. https://doi.org/10.3898/136266213807299023

Mathieson, P. (2015). The Speech of the President and Vice-Chancellor Professor Peter Mathieson to the Court. http://www4.hku.hk/cpao/bulkmail/2015/President/Court/Speech/Court2015f.pdf

Mayo, P. (2008). Antonio Gramsci and His Relevance for the Education of Adults. Educational Philosophy and Theory, 40, 418-435. https://doi.org/10.1111/j.1469-5812.2007.00357.x

Mok, K.-H. (2001). Academic Capitalism in the New Millennium: The Marketization and Corporation of Higher Education in Hong Kong. Policy and Politics, 29, 299-315. https://doi.org/10.1332/0305573012501369 
Ordorika, I., \& Lloyd, M. (2015). International Rankings and the Contest for University Hegemony. Journal of Education Policy, 30, 385-405. https://doi.org/10.1080/02680939.2014.979247

Parmar, I. (2002). American Foundations and the Development of International Knowledge Networks. Global Networks, 2, 13-30. https://doi.org/10.1111/1471-0374.00024

Quinn, K., \& Bates, J. (2017). Resisting Neoliberalism: The Challenge of Activist Librarianship in English Higher Education. Journal of Documentation, 73, 317-335. https://doi.org/10.1108/JD-06-2016-0076

Raaper, R. (2016). Academic Perceptions of Higher Education Assessment Processes in Neoliberal Academia. Critical Studies in Education, 57, 175-190. https://doi.org/10.1080/17508487.2015.1019901

Raaper, R. (2017). "Peacekeepers" and "Machine Factories": Tracing Graduate Teaching Assistant Subjectivity in a Neoliberalised University. British Journal of Sociology of Education, 39, 421-435. https://doi.org/10.1080/01425692.2017.1367269

Raaper, R. (2018). Students' Unions and Consumerist Policy Discourses in English Higher Education. Critical Studies in Education, 61, 245-261.

Shear, B. W. (2008). Gramsci, Intellectuals, and Academic Practice Today. Rethinking Marxism, 20, 55-67. https://doi.org/10.1080/08935690701739964

Thompson, P., \& Diani, G. (2015). Introduction. In P. Thompson, \& G. Diani (Eds.), English for Academic Purposes: Approaches and Implications (pp. 1-8). Cambridge: Cambridge Scholars Publishing.

Wilkesmann, U., \& Lauer, S. (2018). The Influence of Teaching Motivation and New Public Management on Academic Teaching. Studies in Higher Education, 45, 434-451. 